\title{
Thymidylate Synthase
}

National Cancer Institute

\section{Source}

National Cancer Institute. Thymidylate Synthase. NCI Thesaurus. Code C17199.

Thymidylate synthetase protein (312 aa, $36 \mathrm{kDa}$ ) is encoded by the human TYMS gene.

The protein is a conserved transferase enzyme that catalyzes methylene

tetrahydrofolate (MTHF)/dUMP conversion to dihydrofolate/dTMP in thymidine

triphosphate/deoxyribonucleotide biosynthesis. Thymidylate synthetase competes with

the methylene tetrahydrofolate receptor for MTHF and maintains the dT MP pool for

DNA replication and repair. 